\title{
Unhindered medical information access: Health information outreach, the platform for citizen health empowerment
}

\author{
Celina Jummai Nongo, CLN \\ Benue State University, Makurdi, Nigeria \\ E-mail: nongocelina38@gmail.com \\ Nelson E. Ezukwuoke \\ College of Medicine, Enugu State University Teaching Hospital \\ Parklane, Enugu, Nigeria \\ E-mail: ezukwuokeneslson@yahoo.com \\ Mathias Adejoh, $C L N$ \\ Benue State University, Makurdi, Nigeria \\ E-mail: adejomathias@gmail.com
}

\begin{abstract}
This paper focused on theoretical health information outreach which is a pivotal role of the medical librarian to citizenship health empowerment. Dissemination of medical information and access is the service required as the predictor of unhindered medical information. Accessing the information as means of the outreach is where the problems lie. This article identified approaches to information outreach, its challenges in perspective and strategies to enhance health information outreach by medical librarians using the resources in the Libraries as a key to citizenry healthy nation.
\end{abstract}

Keywords: Medical information access, health information access, citizen health empowerment, medical library services

\section{Introduction}

Health is a difficult state to define, but relates to the self-defined perception of an individual and includes physical, mental, social and cultural factors. The absence or deficit of health is illness which includes diseases and injury. Thereafter, diseases cause symptoms, felt, seen or perceived by a person, and signs which may be visible on a medical examination. Illnesses may be from birth (congenital) or arise later in life (acquired). Acquired diseases may be contagious, caused or provoked by lifestyle factors such as smoking, alcohol use and diet, arise as the result of injury or trauma, or have a number of different mechanisms or provoking factors. As life expectancy increases, many forms of diseases emerges.

For example, Ebola, human immunodeficiency virus (HIV) and Acquired immunodeficiency syndrome (AIDS), cancer are becoming more common due to some risk factors. However, health has been defined by WHO (2007) as that state of complete physical, mental and social well-being and not merely the absence of disease or infirmity. According to WHO (2007) the conditions required for health not only include the availability of resources to meet basic human needs and provide protection from all physical and biological environmental hazard but with a sense of 
Celina Jummai Nongo,, Nelson E. Ezukwuoke and Mathias Adejo: Unhindered medical information access: Health information outreach, the platform for citizen health empowerment

security and well-being. If the citizens are faced with health information outreach deficiency, it can lead to both physical and psychological problems. Thus the saying "my people perish due to lack of information". One of the key missions of health or medical librarianship is connecting the public to medical and health information. Activities are grounded in the conviction that health information outreach enables individuals to make better health-related decisions and stay healthier because health remains the primary concern of everyone. Therefore, a healthy population engenders growth through their ability to perform maximally without let or hindrance of qualitative information on health.

The objectives of this paper are to identify approaches to unhindered medical information access which would enhance health information outreach to citizens through the functions of the medical librarians using the libraries and its reputable resources, Identify those challenges encountered in the process of health information outreach, identify strategies to health information outreach, make recommendations that would pave ways to consistently improve on health information outreach to empower the citizenry.

\section{What is health information?}

Health information is defined as any information that enables individuals to understand their health and make related decisions for themselves or their families. Health information is essential in health care and health promotion because it provides both directions and rationale for guiding strategic health behaviors, treatments and decisions. Health information is vital to providing quality patient care of ailments. Therefore available health materials both in hard and softcopies accessing those, assist in health information outreach (Owoaj et.al, 2016)

\section{The importance of health information for the good health of the citizen}

Health information is vital to improving human health and care. Protecting patients from further harm and preserving their rights to life as citizens. At the same time, health information benefit individuals, for example, when it facilitates access to new therapies, improved diagnostics, and more effective ways to prevent illness and deliver care. The primary justification for health information is to protect the health interests of individuals bearing diverse health problems. Its importance can therefore not be overemphasized (Nwafor-Orizu 2013).

\section{Concept of health information access}

According to Garfield (1985) "Medical libraries are established to provide services and health information resources to support and advance the mission to patient care, research and bio-medical education for health institutions." The medical library's position within an organization is therefore strategic and pivotal. It is key to the success and indeed to the very existence of health information access. Health information access is fundamental to individual engagement, which enables one manage chronic or long-term conditions on a day-today basis, it provides progressive plan and make lifestyle adjustments, make informed decisions, and understand how to access health care when necessary as asserted by (Kanj and Mitic(2012).

\section{How citizens gain access to health information}

Citizens' access health information from organized information centers or designated Medical Libraries which can be found in tertiary health institutions or tertiary 
Celina Jummai Nongo,, Nelson E. Ezukwuoke and Mathias Adejo: Unhindered medical information access: Health information outreach, the platform for citizen health empowerment

hospitals with comprehensive information as may be required by clients. Citizens can also gain access to health information through organized advocacy/sensitization or health information outreach. Every citizen as subjects to his or her existing community domiciled in Nigeria is entailed to good health and requires health information because it is important for wellbeing and sustainability by preventing and managing disease, reducing unnecessary disability, premature death, and achieving health equity for all citizenry (Nongo and Ode 2018)

In the Nigerian health sector, there is an urgent need to improve medical library resources and managerial effectiveness. Medical libraries are established to meet health information needs. These cover a broad area of life. Medical information professionals must consider the role they play in the society and their impact on that society. De Gennaro (1984) predicted correctly that:

There is the need to evaluate medical libraries, because in no distant time, the excellence and usefulness of a library will be measured not only by the state and quality of its collections, but also by the range of resources that its staff are able to deliver to users by conventional and electronic means from a growing variety of services. Users will no longer ask what the library has, but what it can provide.

\section{Citizen health empowerment}

The citizen is one who is legally given right to belong to a particular country. In perspective the citizen from Nigeria is regarded as one who is born in Nigeria, he has the rights and privileges of a freeman in a country, native or naturalized person who owes allegiance to a government and is entitled to protection from it.
Citizen health empowerment depends on the quality of literature on health which was exposed towards averting presumed health deficiencies to the citizenry. Feste and Anderson(1995) cited in Anyaoku (2014) defined empowerment as "an educational process designed to help patients develop the knowledge, skills attitude and degree of self-awareness necessary to effectively assume responsibility for their health related decisions". Nongo and Ode (2018) opined that "the key to successful realization of Sustainable Development Goals (SDG) 3 focus on good health and wellbeing of citizens in Nigeria, is advocacy/sensitization of preventive health care for all ages.

The Nigerian health system indices shows that between 2005 to 2015 indicate over 40 percent of all countries have less than one physician per 1,000 people, and around half have fewer than three nurses or midwives per 1,000 people. Almost all least developed countries are the reverse. This factor stresses the need for more hands to handle health information outreach to the vulnerable citizens in the country (Araoye, 2011).

\section{Medical librarians and their roles in creating access to health information}

Without thoughtful rationale and direction, medical library as agents to health information outreach whose activities may simply be immediate responses to service requests or service needs perceived during patrons' use of the library. A well-informed Health Information Officer (HIO)but,with unfocused efforts by staffers can result in redundant and uncoordinated outreach that cannot be sustained. There are rich opportunities for libraries conducting information-oriented outreach to members of the public or health workforce. This brings to the fore medical library roles in providing health information access to her 
Celina Jummai Nongo,, Nelson E. Ezukwuoke and Mathias Adejo: Unhindered medical information access: Health information outreach, the platform for citizen health empowerment

teaming users as enumerated by (Walzer, Stott \& Sutton 2000):

1. Provision of current information to users in a quick and cost effective manner at the readers services section

2. Provision of value services, which improves information access and outreach delivery.

3. Dissemination of health information and promotion of healthy lifestyles through advocacy and sensitization.

4. Satisfying the health information needs of the citizens in the community through selective dissemination of information (SDI)

5. Locating and assisting in the development of relevant information or materials on the shelves for easy access through the organized National Medical Association cataloguing and classification tools.

6. Pairing information outreach with other activities in which the populations already engaged e.g. workshops, conferences, community events etc and

7. Integrating health information literacy into ongoing programmes of the target population in the community. The roles cannot be overemphasized as the tasks are enormously outlined.

The following figure shows various sections headed by the librarian in a typical medical library.

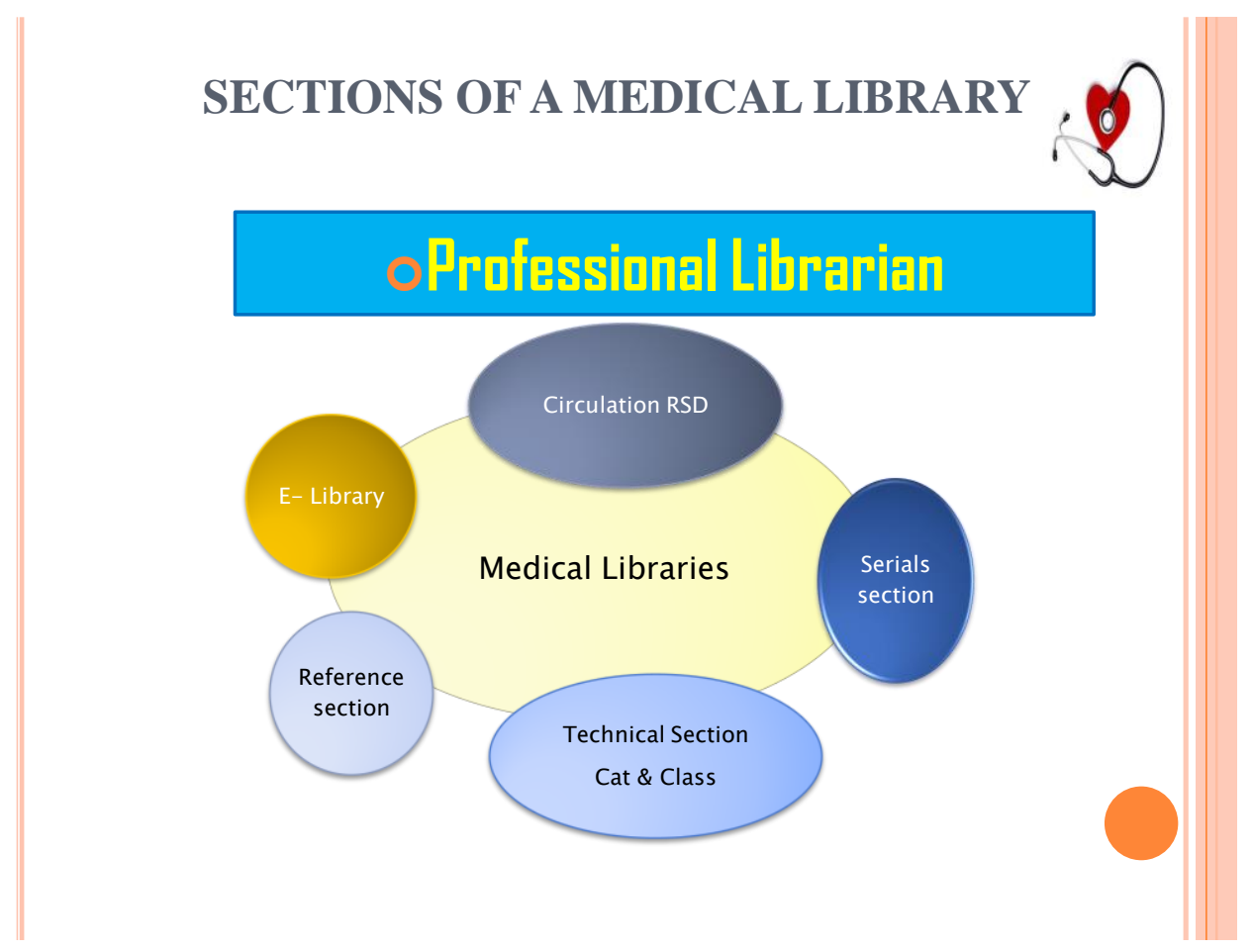

Figure 1: Sections of a Medical library

Source: College of Health Science, Benue State University Organogram (2015) 
Celina Jummai Nongo,, Nelson E. Ezukwuoke and Mathias Adejo: Unhindered medical information access: Health information outreach, the platform for citizen health empowerment

\section{Health information outreach}

What is health information outreach? It could be described as "Extending the provision of library services beyond the physical boundaries of the library." Therefore health information outreach is the process of disseminating health information to the citizenry beyond the physical boundaries of the library which empowers the decision on certain diseases which may be due to lifestyle or hereditary as the case may be.

Health information outreach (HIO) is an act performed by the Medical Librarians in rendering services of literature search or consultancy of information services through the Medical Librarian. This function leans more towards document delivery which pertains to medical information outreach by Librarians expeditiously through the Medical Library. Health Information Outreach is a service commonly pursued by medical libraries. Health information outreach activities in libraries have the potential to involve many staff members, serve multiple audiences, using several project strategies to carry out health information outreach.

\section{Medical librarians and health information outreach in Nigeria}

Medical librarians found in both tertiary institutions and hospitals generate, organize and provide access to health information sources. The primary objective is to promote health, wellbeing, reduce mortality and morbidity in populations, which is what the United Nations (UN) agreement on Sustainable Development Goals (SDG) 2030 focuses on. The Goal 3 target which is "Good health and wellbeing for all at all ages" borders on pressing international and national health concerns. Therefore, it is the duty of medical librarians establishing access to health information and outreach for the achievement of SDG-3, this remains a key function for medical libraries across the globe.

Consequently, medical librarian uses her professional staff to carry out the task of qualitative bibliographic literature search, plans and execute effective health information outreach. Thus such projects within the system are essential to ensure continuity of health information outreach to her teaming citizens in the community at large.

According to Anyaoku (2016) medical libraries are institutions for health information dissemination and access. They are set up to collect, organize and disseminate health and well-being information in a health, hospital or academic setting. They support medical doctors, nurses, pharmacists, other allied health professionals and students in learning, knowledge acquisition and research through provision of information resources that cover all areas of medical specialties. Evidently her assertions portray medical libraries as agents to provide unhindered access to medical information in whatever format, be it print and non-print, e-resources, monographs, serials etc.

Zakari and Nongo (2016) asserted that, the increasing competitiveness of the health care market place and the need for information dissemination by service providers has increased considerably, there is a dare need to strategize using the competitive intelligence systems as a vital tool or source for information outreach. The application of competitive intelligence into the medical library services will enhance the driving innovation and creativity in library and information centers to keep pace with the fast changing knowledge society. The provision of easy access to health information on the internet or web have considerably increased expectations of library users who expect same speed, breath 
Celina Jummai Nongo,, Nelson E. Ezukwuoke and Mathias Adejo: Unhindered medical information access: Health information outreach, the platform for citizen health empowerment

and comprehensiveness in information services and outreach.

However, to meet the sustainable development goals health targets by 2030 , progress must be accelerated, many more efforts are needed to fully eradicate a wide range of diseases and address many differences persistent and emerging health issues in particular to our region with the highest burden of diseases; for instance, infectious diseases, non-communicable diseases, mental disorder and other health risks.

Aina (2014) study recommended the need to improve on information awareness, provide health facilities that can positively benefit rural women of reproductive age in Ogun State. Health information outreach will in many ways avert mortality rate if awareness is enhanced using so many approaches as listed above.

In the same vein, Paulina and Abdulsalami (2013) suggested that information and communication technology (ICT) plays a significant role in war against HIV/AIDS due to enlightenment campaign to control the pandemic. ICT facilities assist in the delivery of critical services such as the health information. Some of the facilities used in the rapid transmission of information over a short or long distance are; electronic mails, Satellite, outreach through subscribing to e-health and $\mathrm{m}$-health etc.

WHO (2011) defined m-health as the use of mobile and wireless technologies to support the achievement of health objectives. It is a tool for promoting healthy behaviour and strengthening health systems through health interventions such as maternal \& child health, HIV \&AIDS, family planning, malaria etc. It improves access to health information and services for underserved populations in communities.

Both m-health and e-health involve the application and use of ICTs to support health information outreach and healthrelated activities. M-health is the use of mobile and wireless ICTs for health, including mobile phones, tablets and other mobile devices, but not laptops or servers while the e-health is the application of ICTs for health information outreach, including laptops, desktop computers and servers, television and radio, teleconferencing systems, and all of the devices used in mHealth.

\section{Below are diagram of mobile technology used in m-health and e-health}
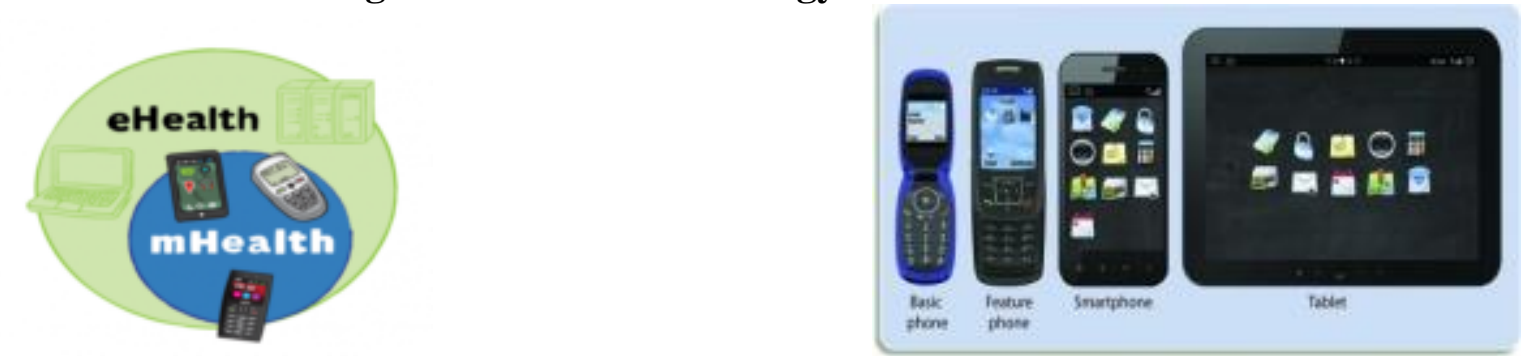

Figure 2: Mobile technology used in m-health and e-health

Source: Management Science for health handbook (2005)

Medical librarians serve as professionals providing quality information for improved health through its advocacy and sensitization programs and services; it has served societies by providing quality information for better health care and proffer public's understanding of health. Although the core values and vision of medical Librarians remain unchanged, they build on the past 
and reengineer themselves to meet the information-intensive demands of health care of the future for its citizenry. The medical librarian profession's remains vital and essential in the $21^{\text {st }}$ due to its roles in creating access to health information and outreach services. Their traditional skills including reference interview skills and online retrieval skills are those used most frequently in the health care setting. Medical librarians have developed knowledge base of clinical medicine as expertise in evidencebased medicine, and the techniques of information retrieval skills remains sacrosanct (Nongo \& Ode, 2018)

Medical librarians in creating health information outreach provide evidential based information to medical educators hence the concept of evidence-based medicine. The integration of bibliographic search into medical students training involves the medical librarian who is required in consultation to teach medical students on how to use medical literature for the purpose of health information outreach.
It is an obligatory function of the medical librarian to disseminate health information being the experienced searcher on medical sciences resources. The advent of Pubmed, Medline and Web technologies has improved effective evidence based medicine information retrieval processes. Therefore Computers are essential tools for medical librarians in creating, accessing and disseminating health information. Its evolution enhances effective and efficient health information delivery to Citizens (Anyaoku, 2016).

Below are a selection of days among others set aside for awareness and national health campaign to sensitize citizens on wellbeing, strategic activities on diseases and their information access provided by the Librarian who would qualitatively prepare bibliographic literature search on those ailments in collaboration with health workers for onward dissemination of information through exhibitions of the literature, advocacy and sensitization to empower her citizenry effectively. Few dates and months are tabulated as follows: 
Celina Jummai Nongo,, Nelson E. Ezukwuoke and Mathias Adejo: Unhindered medical information access: Health information outreach, the platform for citizen health empowerment

Table 1: Dates for health sensitization of various diseases

\begin{tabular}{cll}
\hline S/N & $\begin{array}{l}\text { Dates for } \\
\text { sensitization }\end{array}$ & Types of dieases \\
\hline 1 & $4^{\text {th }}$ February & World Cancer Day \\
2 & $20^{\text {th }}$ March & World Oral Health Day \\
3 & $24^{\text {th }}$ March & World T B Day \\
4 & $4^{\text {th }}$ April & World Autism Day \\
5 & $7^{\text {th }}$ April & World Health Day \\
6 & $25^{\text {th }}$ April & World Malaria Day \\
7 & $31^{\text {st }}$ May & World No Tobacco Day \\
8 & $14^{\text {th }}$ June & World Blood Donor Day \\
9 & $19^{\text {th }}$ June & World Sickle Cell Day \\
10 & $27^{\text {th }}$ June & National HIV Testing Day \\
11 & $28^{\text {th }}$ July & World Hepatitis Day \\
12 & 29 th September & World Heart Day \\
13 & $10^{\text {th }}$ October & World Mental Day \\
14 & $15^{\text {th }}$ October & Global Hand washing Day \\
15 & $12^{\text {th }}$ November & World Pneumonia day \\
16 & $14^{\text {th }}$ November & World Diabetes Day \\
17 & $2^{\text {nd }}$ December & World Aids day etc \\
\hline
\end{tabular}

Source: National Hospice and Palliative care (2017)

\section{Approaches to health information outreach for librarians in Nigeria}

There are about four approaches or steps to an effective health information outreach programme in Nigeria as cited by Aborlarin, (2017). as the approaches to a desired health information outreach are as follows:.

1. Garner current statistical background information about the community or place of outreach. These would include their demography as well as health deficiency indices.

2. Assess the medical library acquisitions of material holdings including online, monographs, serials and references.
3. Establish cordial contacts with health professionals and health workers prior to developing relationships towards the HIO.

4. Establish cogent plans and implement health information outreach program effectively.

\section{Challenges of effective health information outreach for librarians in Nigeria}

Inspite of the need to sensitise citizens on health information, the researchers, envisaged possible challanges of carrying out health information outreach as follows: 
Celina Jummai Nongo,, Nelson E. Ezukwuoke and Mathias Adejo: Unhindered medical information access: Health information outreach, the platform for citizen health empowerment

i. Architectural defects by noninclusion of exhibitory space: Most of the medical libraries lack space and accommodation within the building for exhibition purposes. This factor is a major obstacle to carrying-out health information outreach within the university or hospital environment.

ii. Staff mind-set towards bibliographic literature search: Some staff of the medical libraries portrays non participatory and nonchalant attitudes towards the act of selective dissemination of information and bibliographic literature searches. Their attitude to work is not target oriented and it therefore affects realization of outreach on the specified and designated sensitization dates of health information outreach which remains inconclusive and never enforced or implemented.

iii. Team work inadequacies: Leadership role of the medical library management affects decisions negatively, which is due to lack of cordination of the planned outreach activities.

iv. Inadequate professional personnel: Planning and execution of health information outreach requires professional librarians initiatives to properly execute it successfully. the challenge of inadequate professional librarians affects the presumed outreach.

v. Ineffective health information outreach in perspective: The challenge of establishing criteria for selecting participatory experienced staff, determining the health outreach focus, developing and conducting the advocacy is a major factor.
Therefore, a well-intentioned but unfocused effort can result in redundant and uncoordinated projects that cannot be sustained.

vi. Inadequate finance for consistency of health information outreach: The area of strategic planning and funding sources, be it internal ensures that outreach activities are expressions and programme of the library's mission. Funding requires flexible and target oriented programs and sustain successful ones and avoid mistakes.

\section{Enhancement of effective health information outreach by librarians in Nigeria}

Medical libraries can facilitate online access to health information among vulnerable and underserved populations through blogs etc. this can help patrons' or consumers recognize the need for health information by identifying problems associated with lack of relevant information for guiding good health decisions and achieving desired health outcomes.

Consequently, strategies for medical libraries health information outreach are;

i. Inclusion of exhibitory space on architectural planning of the medical libraries as well as inclusion on budgetary plans.

ii. Enforcement of staff orientation on bibliographic search as an obligation of professionalism.

iii. Encourage team work in the medical libraries demonstrating leadership by example.

iv. Recruitment of medical library personnel should be based on discipline oriented, that is he or she should have at least a BSc in library education as fundamental requirement and a science combination in subjects. 
Celina Jummai Nongo,, Nelson E. Ezukwuoke and Mathias Adejo: Unhindered medical information access: Health information outreach, the platform for citizen health empowerment

v. Medical library budgetary proposal for yearly health information outreach should be presented to college management or hospital management prior to budget defense, in doing so, planning and execution of health information outreach is optimistic.

\section{Conclusion}

Medical libraries play essential non-partisan roles in providing health information that allows users to make informed decisions. Better-informed citizens may provide another incentive for clinicians to be more aware of research findings which drives towards evidence based medicine. A health empowered citizen accesses information on clinical effectiveness in order to improve the quality of care and to stay well-informed on developments in specialist areas of health needs.

Second, the medical library institution's definition of outreach should be based on a strategic plan for outreach. Strategic planning has been an important component of targeted oriented practices within the library and it is widely recognized as an effective planning tool in libraries. Therefore, the systematic development of an outreach plan can be key to the success of outreach activities. A comprehensive outreach plan should include detailed goals and objectives, assessment and evaluation methods, using a marketing strategy. A strategic approach to outreach can turn haphazard outreach efforts into a single focused program that would enhance a medical library ability to deliver health information to its patrons.

Medical libraries play a critical role in medical education and provide a balanced perspective on medical issues. In addition, a variety of services have been developed to improve health information outreach. Information providers are convinced that medical libraries are useful; however, this is not enough. The value of our activities must be demonstrated regularly, using both qualitative and quantitative information outreach.

The following are recommended in the light of what has been presented in the paper:

i. Medical librarians must define their user communities, understand what their health indices are and develop on the necessary health collections.

ii. The hospital and university management should consider employment of professionals who have academically acquired the basics of librarianship.

iii. Funding must be addressed and presented before the ministry of health for consideration and necessary assessment towards budget inclusion that authenticates the benefits of the medical libraries in empowering its citizens on health information.

iv. Include strategic planning for finding, filtering information and methods of improving health information dissemination.

v. Medical libraries must make use of basic statistics on health based indices, show casing performance metrics, and share those data to users or researchers. Those selected metrics would demonstrate the amazing value and impact of libraries in their communities. All stakeholders must help to ensure that we communicate this impact and value.

\section{References}

Abolarinwa S.T. (2017). Health information literacy: $8^{\text {th }}$ Medical Library 
Celina Jummai Nongo,, Nelson E. Ezukwuoke and Mathias Adejo: Unhindered medical information access: Health information outreach, the platform for citizen health empowerment

Association Conference paper. Ilorin: Kwara State. Nigeria.

Akidi J.O et al (2012). Recreating reference and information services in academic libraries in the digital age. Global review of Library and Information Science, 8, 87-102.

Aina, R. F. (2014). Awareness and use of information on safe motherhood among rural women of reproductive age in Ogun State Nigeria. Journal of Health Information and Librarianship, 2 (1\&2), 1-9

Anyaoku E.N. (2016). Empowering patients for chronic disease self-management through acces to health information in Nigeria: overview of strategies. Journal of Health information and Librarianship, 2(1\&2), 22-29

Araoye M.A. (2011). High-blood pressure, the silent killer: when salts becomes poisons: A valedictory lecture at College of health sciences Benue State University, Makurdi.

Funso, F.J. (2014). Self empowerment: A Strategy for reducing ill-health among Nigerian youths Journal of Health Information and Librarianship, 2(1\&2), 14-21

Feste, C \& Anderson, R (1995). Empowerment: From philosophy to practice. In Assal, J.P. and Visser A.P (eds). New trends in patient education. Amsterdam: Elsevier Science.

Gboyega, A., Akewukereke, M.A. \& Ibitoye S. O. (2007). The effect of medical libraries on medical education: evidence from Osun State, Nigeria. Library Philosophy and Practice. Retrieved from https://digitalcommons.unl.edu/cgi/vi ewcontent.cgi? article $=1159 \&$ context $=$ libphilprac.

Health Care awareness calendar: key months, days from January-
December (2018). Retrieved from https://www.beckershospitalreview.c om/quality/healthcare-awarenesscalendar-key-months-weeks-anddays-fro

https://www.healthpartners.com/providerpublic/cultural-care-resourcesstating-an-effective health-outreachprogramm/ accessed on the 1/3/2019

https://www.ncbinlm.nlm.nih.gov/books/NB K9579 accessed on 1/3/19

Kanj and Mitic (2012). Health literacy Retrieved from .https://www.nih. gov/institutes-nih/nih-officedirector/office-communicationspublic-liaison/clear-communic $\% 20$ ati\%20on/health-literacy

Management Science for Health (2010). Health systems in action: An ehandbook for leaders and managers. College of Health Sciences, Benue State University.

Merriam-webster dictionary. Retrieved from .https:/ /www. merriam-webster.com /dicti onary/citizen.

Mole, A.J. (2006). The challenges of information and communication technology (ICT) in Reference Services in University Libraries. Global Review of Library and Information Science, 2, 45-55.

National Hospice and Palliative Care Organization: Retrieved from https://www.nhpco.org/publications/ 2017-health-observance-dates.

Nongo, C. J. \& Ode, M. (2018). Information literacy for sustainable development goals in Nigeria: implication for healthy living. $20^{\text {th }}$ National Association of Library and Information Educators Conference. Benue State Makurdi.

Nwafor, O. (2013). Health information and utilization for effective health care delivery by Doctors in teaching hospitals in South-East Nigeria: an 
Celina Jummai Nongo,, Nelson E. Ezukwuoke and Mathias Adejo: Unhindered medical information access: Health information outreach, the platform for citizen health empowerment

unpublished dissertation, Department of Library and Information Science. UNN.

Owoaj, E.T. et al. (2016). A Review of the Health problems of the internally displaced persons in Africa. Nigerian Postgraduate Medical Journal, 23(4)

Paulina, F. S. \& Abdulsalami, T.L. (2013). Application and use of ICT facilities available for the enlightenment of HIV/AIDs in Nigeria. Global Review of Library and Information Science, 9, 97-107.

Umunna, O. (2005). Reference Services and ICT Curriculum Development in Library Schools in Nigeria. A Compendium of Papers presented at the 2005 National Interactive Seminar on Application and Utilization of ICT for Reference Services in Libraries and Information Centres at the National Library of Nigeria, Plateau State Branch. Jos, 26-28, April.

World Health Organization. (2007). everybody's business: Strengthening health systems to improve health outcomes-WHO's Framework for Action. Geneva.

www.ahima.org/careers/healthinfor accessed on $1 / 3 / 2019$

Zakari, A. \& Nongo, C. J. (2016). Creating value based medical library services through competitive intelligence. Journal of Health Information and Librarianship, 3(1), 16-20.

\section{About the authors}

Celina Jummai Nongo is a Librarian II and currently the Faculty Librarian at Benue State University Library and Information Services Makurdi Benue State, Nigeria. She holds Bachelor of Science, Master of Library and Information Science and presently awaiting schedule for her Ph.D oral defense in Library and Information
Science at the University of Nigeria Nsukka, Enugu State Nigeria.

She is a fellow of Management Science for Health Professionals, Certified Medical Librarian, a Certified Librarian of Nigeria and Member, Nigerian Library Association. She has held various positions in the Library: Chairperson, Publicity and Marketing Committee of the University Library, Head of Readers Services (Medical Library of the College of Health Sciences), Head of Quality Assurance, Head of Collection Development and presently Head of 7 Faculty Libraries.

She has attended numerous local and international conferences and presented papers, amongst others is the recent $16^{\text {th }}$ AHILA [Association for Health Information and Libraries in Africa] Biennial Conference. Attended a number of systematic review training courses.

She has authored and co-authored a number of publications both in medical librarianship and core trending librarianship profession. She has served as facilitator and member LOC in training, conference, seminars and workshops. Her research interest include librarianship ethics, technologies, health information system, trends in library entrepreneurship and school librarianship.

Nelson E Ezukwuoke is a Medical Librarian with Enugu State University Teaching Hospital, Parklane, Enugu, Nigeria $\mathrm{He}$ is Librarian I. He is vast in Health related publications.

Mathias Adejo is an Assistant Librarian working at the Collection Development Unit, Benue State University, Makurdi, Nigeria. He holds BSc (LIS) and MLS and has co-authored various articles. 